\title{
PSIKOSOSIAL ANAK DALAM KUMPULAN DONGENG BAGAI BUMI BERHENTI PERPUTAR DAN SEJUTA WARNA PELANGI KARYA CLARA Ng
}

\author{
Sri Utami Affrilia Dewi \\ SMA Raudlatul Mutaallimin Datinawong Babat \\ HP 081232753553; Pos-el: sriutamiaffriliadewi54@gmail.com
}

\begin{abstract}
Abstrak: Tujuan penelitian ini untuk: Mendeskripsikan bentuk-bentuk Psikososial 1) Kepercayaan versus Kecurigaan. 2) Otonomi versus Perasaan Malu dan Ragu-ragu. 3) Mendeskipsikan bentuk Psikososial Inisiatif versus Kesalahan. 4) Integritas versus Keputusasaan dalam kumpulan Dongeng Bagai Bumi Berhenti Berputar dan Sejuta Warna Pelangi karya Clara Ng. Untuk memahami dan mengapresiasi karya sastra (dogeng), peneliti menggunakan pendekatan formalis/ New Criticism, yaitu peneliti memperhatikan kensenyawaan struktur dan kontruk karya. Sebuah karya dinilai keberhasilan dan kemantapannya melalui bentuknya, yakni melihat keutuhan strukturnya dengan memeriksa antara hubungan dan jalinan keterakitan sesama elemen satrawi pendukungnya. Menurut pendekatan formalis, teks sastra adalah objek yang harus dianalisis untuk dapat menemukan maknanya. Singkatnya, tujuan dari pendekatan formalis adalah untuk mengetahui apakah isi sebuah karya dan bagaimana isi itu disampaikan (Sarumpaet, 2010: 39). Hasil penelitian sebagai berikut. 1) Aku jadi takut mendengar kata-kata2) senang sekali bisa pulang ke Indonesia3) Dan negara itu sangat jauh dari Indonesia 4) Bintang, tetaplah bersinar agar Pipi tahu Bunda baikbaik saja di atas sana.
\end{abstract}

Kata kunci: dongeng, psikososial, anak.

\begin{abstract}
The purpose of this study is to: Describe the Psychosocial Form of1) Trust versus Suspicion. 2) Autonomy versus Shyness and Hesitation. 3) Initiative versus Error form. 4) Integrity versus Despair in a collection of Tales Like Earth Stop Rotating and Million Colors of Rainbow by Clara Ng.To understand and appreciate literary works (dogeng), researchers use a formalist / New Criticism approach, that is, researchers pay attention to the complexity of the structure and constructs of the work. A work is judged by its success and stability through its form, which is to see the integrity of its structure by examining the relationships and intertwined relationships of its supporting elements. According to the formalist approach, literary text is an object that must be analyzed in order to find its meaning. In short, the purpose of the formalist approach is to find out whether the contents of a work and how the content is delivered (Sarumpaet, 2010: 39).The results of the study are as follows. 1) I'm so scared to hear the words 2) It's great to go home to Indonesia 3) And the country is very far from Indonesia 4) Star, stay shining so Pipi know Mother is okay up there.
\end{abstract}

Keywords: fairy tales, psychosocial, children. 


\section{PENDAHULUAN}

Karya sastra merupakan hasil karya manusia yang bersifat imajinatif. Sebagai hasil imajinatif, sastra berfungsi sebagai bahan bacaan yang menyenangkan, di dalamnya sarat dengan nilai-nilai budaya yang berguna menambah kekayaan batin manusia, kemanusiaan, dan kehidupan (Nurgiantoro, 2007:2). Setiap manusia merupakan individu yang berbeda dengan individu lainnya. Karya sastra lahir dari latar belakang sosial yang berbeda-beda. Karya sastra sebagai kenyataan sosial, meniru alam dan dunia subjektif manusia. Karya sastra sebagai produk psikososial membahas tingkah laku manusia sebagai individu dan masyarakat. Psikososial bertujuan untuk mengerti suatu gejala yang timbul dari perilaku tokoh. Dengan mengerti suatu fenomena, kita dapat membuat peramalan-peramalan tentang kapan akan terjadinya fenomena tersebut. (Sarwono, 2014: 4).

Karya sastra memerlukan bantuan psikologi karena pada hakekatnya merupakan produk dari sesuatu keadaan kejiwaan dan pemikiran pengarangnya (Semi, 1993:70). Hal ini tidak terlepas dari prinsip yang menyatakan, bahwa manusia pada dasarnya terdiri atas jiwa dan raga. Penelitian yang menggunakan psikologi terhadap karya sastra merupakan bentuk pemahaman atas penafsiran karya sastra dari sisi mengamati tingkah laku tokoh-tokoh dalam sebuah roman drama, dan dongeng untuk menjelaskan dan menafsirkan karya sastra (Hardjana, 1994: 66).

Berdasarkan uraiandi atas, bahwa dongeng atau cerita mempunyai lingkup sendiri yang di dalamnya terdapat tokohtokoh yang mempunyai karakter berbedabeda. Karakter tokoh tersebut dapat diamati dalam peristiwa yang dicerminkan dalam karya. Khususnya kumpulan dongeng Bagai Bumi Berhenti Berputar dan Sejuta Warna Pelangi Karya Clara $\mathrm{Ng}$ sebagai objek penelitian dengan mengunakan pendekatan Psikososial. Alasan peneliti mengambil dongeng tersebut karena: Cerita tersebut belum pernah diteliti oleh siapapun. Isi cerita menarik dan sesuai dengan perkembangan usia anak. Pesan moral atau pendidikan menyentuh kepada orang tua dan guru. Clara $\mathrm{Ng}$ adalah penulis cerita anak yang produktif. Cerita Clara $\mathrm{Ng}$ ini pernah meraih juara Adikarya IKAPI. Kedua buku cerita ini membantu anak-anak memahami perasaan mereka; membantu mengingatkan bahwa mereka tidak sendirian. Kedua buku ini juga menolong anak-anak berempati kepada anak-anak lain yang kebetulan sedang mengalami peristiwa dan memiliki rasa empati terhadap peristiwa menyedihkan di dalam keluarganya.

Penelitian ini bertujuan untuk: mendeskipsikan bentuk Psikososial Kepercayaan versus Kecurigaan; mendeskipsikan bentuk Psikososial Otonomi versus Perasaan Malu dan Ragu-ragu; mendeskipsikan bentuk Psikososial Inisiatif versus Kesalahan; dan mendeskipsikan bentuk Psikososial Integritas versus Keputusasaan yang muncul dalam kumpulan Dongeng Bagai Bumi Berhenti Berputar dan Sejuta Warna Pelangi karya Clara Ng?

\section{METODE PENELITIAN}

Penelitian ini dibentuk dengan metode penelitian deskriptif kualitatif. Pengumpulan data dengan teknik simak karena yang digunakan untuk memperoleh data dilakukan dengan menyimak penggunaan Bahasa (Mahsun, 2011:92).

Pengumpulan data dengan menggunakan teknik catat adalah dengan 
mencatat segala informasi. Sudaryanto (1993: 136) mengatakan pencatatan dapat dilakukan langsung ketika teknik pertama atau kedua selesai digunakan atau sesudah perekaman dilakukan, dan dengan menggunakan alat tulis tertentu. Dengan adanya kemajuan teknologi, pencatatan ini dapat memanfaatkan disket komputer.

Analisis data penelitian ini menggunakan beberapa tahapan: 1) mendeskipsikan bentuk psikososial kepercayaan, 2) mendeskipsikan bentuk psikososial otonomi, 3) mendeskipsikan bentuk psikososial inisiatif, dan 4) mendeskipsikan bentuk psikososial integritas.

\section{HASIL PENELTIAN DAN PEMBAHASAN \\ Psikososial Kepercayaan versus Kecurigaan}

Si anak mempunyai keyakinan dan keraguan dalam hatinya mengenai sesuatu yang pernah dijalaninya. Keyakinan anak dipengarhui oleh orang terdekatnya. Baik itu ibu atau pengasuhnya. Sherif dan Hovland ( dalam Sarwono 2014: 187) mengatakan bahwa pembentukan situasi ini mencakup faktor-faktor intern maupun ekstern. Interaksi dari faktor-faktor intern dan ekstren ini yang menjadi acuan dari setiap perilaku. Sebagaimana kutipan: "Malam itu Mama tidak menemaniku makan. Kulihat Papa dan Mama berbisikbisik. Aku jadi takut mendengar katakata, "Adik...sakit...kanker," (Clara, 2017a:8).

Berdasarkan data di atas, anak mempunyai keyakinan bahwa penyakit kanker adalah penyakit yang mematikan dan tidak ada obatnya sampai sekarang. Tentu, anak beranggapan bahwa keraguan kalau kanker bisa disembuhkan. Nah, dalam sanubari anak timbul pertanyaan apakah kanker itu? Akhirnya anak mengetahui dari pembicaraan papa dan mama. Perhatikan kutipan berikut.

Kanker itu apa ya? Aku ingin bertanya. Tapi tidak berani. Melihat cara Papa dan Mama berbicara, mungkin kanker sesuatu yang menakutkan (Clara, 2017a:11).

Anak seusia SD tentu banyak yang belum mengerti tentang kanker itu, di sini pengarang mengajak kepada anak-anak agar selalu menjaga kesehatan. Dengan tetap memperhatikan makan yang bergizi dan kebersihan. Akhirnya anak tidak takut dan mengerti mengenai kanker dari penjelasan ibu. Setelah ada penjelasan, anak mengerti bahwa kanker itu salah satu penyakit yang disebabkan virus. Untuk mencegah kanker, makan makanan bergizi, istirahat cukup, dan rutin periksa ke dokter serta selalu berdoa kepada Tuhan.

Manusia adalah makhluk yang unik, keberadaanya menimbulkan misteri. Dalam kaitan ini, memahami kejiwaan sastra secara psikologis berarti suatu keharusan. Atas keanehan itu manusia justru menarik untuk dibahas. Dari sisi apa pun, termasuk sastra dan psikologi, manusia semakin aneh saja. Fenomena dasar manusia, memang sulit diduga. Kejiwaan manusia kadang tetap, kadang stabil, begitu pula ketika bersentuhan dengan sastra, manusia selalu menunjukkan hal-hal yang di luar kebiasaan (Endraswara, 2008: 17). Sang ayah menanamkan keyakinan kepada anaknya, bahwa orang yang meninggal dunia akan mendapatkan balasan sesuai dengan amal ketika ia masih hidup. Perhatikan kutipan ini.

"Pipi, "kata Ayah lembut. "Tidak ada seorang pun yang tahu apa yang terjadi saat setiap makhluk meninggal. Tubuh mereka tidak lagi bekerja. Jantung mereka berhenti berdetak. Mereka juga tidak bernapas dan tidak sadar lagi. 
Bunda meninggal dengan tenang, dan Ayah percaya saat ini Bunda pasti berbahagia." (Clara.2017a:64).

Jika manusia meninggal dunia, ia hanya mengharapkan doa dari keluarga yang masih hidup. Usia anak kecil yang ditinggal oleh ibu kandung bagaikan anak ayam kehilangan induknya. Kesediahan keluarga tergambarkan pada:

"Pipi ingin Bunda sehat-sehat saja. Yah". Kata Pipi. Mulai merasa sedih. "Ayah pun begitu, Pi. Tapi apa pun yang terjadi, Bunda tidak akan pernah kembali lagi. Yang bisa kita lakukan adalah mengenang semua kebaikan hati Bunda. Mengenang kegembiraan yang diciptakan Bunda di keluarga kita. Pipi tentu tidak akan melupakan Bunda, bukan?" Pipi mengeleng (Clara,2017a:66)

Pipi masih membutuhkan kasih sayang ibu. Tiba-tiba ibundanya menghadap Sang Pencipta. Ayah hanya bisa memberikan hiburan bahwa bunda baik-baik saja di alam sana. Sang ayah memberikan metafor kepada Pipi, bahwa bundanya adalah seperti bintang di langit yang selalu memancarkan cahaya. Putuslah amal manusia ketika meninggal dunia. Kecuali tiga perkara, yaitu: sodakoh jariyah, ilmu yang bermanfaat, dan doa anak yang saleh.

Psikososial Otonomi versus Perasaan Malu Pada dasarnya anak usia sekolah menunjukkan tanda-tanda lebih dekat dengan guru dibandingkan dengan orang tuannya. Ia aktif dalam kegiatan lingkungannya, dan suka bertanya-tanya karena perhatiannya sangat tajam. Mereka seperti realis kecil; ingatannya sangat setia dan kemauan belajar yang kuat. Karena itu perlu diberi motivasi di samping harus menjauhkan saran dan sugestif yang dilarang oleh ajaran agama seperti yang bersifat asosial dan asusila (Zulkifli L, 1986: 61-62).

Yuli, salah satu tokoh yang ada dalam cerita Seribu Sahabat Selamanya karya Clara Ng. Pada awalnya ia tidak mau diajak ke luar negeri oleh orang tua karena berbagai alasan. Alasan yang pertama, ia khawatir kehilangan teman akrabnya. Kedua, ia sangat cinta kepada gurunya. Perhatikan kutipan:

"Libur telah tiba! Yuli senang sekali bisa pulang ke Indonesia, bertemu dengan sahabat-sahabatnya. Ia juga akan bertemu dengan Nenek dan Kakek. Yuli rindu sekali bertemu dan bermain dengan mereka" (Clara.2017b:30).

Melihat Yuli kesal dan kecewa, akhirnya sang ayah menghiburnya dengan membelai rambut sebagai tanda kasih sayang. Orang tua yang bijaksana, tentu akan merasakan apa yang sedang dialami buah hati. Ada waktu untuk memberikan kasih sayang kepada keluarga terutama untuk anak. Anak mempunyai otoritas mengatur dirinya sendiri sesuai denga taraf perkembangannya. Orang tua berkewajiban mengarahkan mereka agar memiliki kepribadian sesuai denga ajaran agama dan budaya masyarakatnya. Yuli mempunyai kemauan yang kuat untuk tetap belajar dan menghormat kepada guru yang dicintainya. Kepergian Yuli ke luar negeri menambah suasana pertemanan menjadi lebih akrab.

Berbeda lagi dengan Donna dan Daniel, dua anak yang tidak mempunyai otoritas karena ditinggal orang tua karena kasus cerai ayah dan ibunya. Meraka malu melihat orang tua selalu bertengkar karena adanya kesalahpahaman. Akhirnya, perkembangan psikologis anak mudah merasa salah. Perhatikan kutipan:

"Donna menunduk, teringat wajah Daniel yang menangis dalam kegelapan kamar mereka. "Bu. Apa salah Donna sampai Ayah meninggalkan rumah?" (Clara.2017a:85).

Tokoh Donna dan Daniel menjadi tumpuhan penelitian psikologi sastra, 
berarti perlu diidentifikasi. Jangan-jangan kedua tokoh tersebut menjadi cermin diri sastrawan. Tokoh tersebut tergolong orang-orang yang diamati oleh pengarang (Clara Ng) dan pengarang sendiri masuk secara alamiah dalam karyanya (Endraswara, 2014: 184-185).

Penyajian watak tokoh dalam dongeng jelas banyak memainkan peran aspek psikologis. Bagaimana rasanya anak-anak yang ditinggal cerai oleh orang tua. Tentu tidak enak, siapa yang harus didekati? Binggung kan? Harta benda yang diberikan belum seberapa, tetapi mereka membutuhkan kasih sayang.

Materi yang diberikan kepada anak sebesar apa pun kurang berarti dalam otoritas perkembangan anak. Anak membutuhkan kasih sayang dari orang tua. Anak yang saleh dilahirkan dari keluarga yang saleh pula. Perhatikan dan berikan kasih sayang kepada mereka. Tentunya kelak mereka akan menjadi insan yang bermartabat dan generasi yang hebat.Dunia anak adalah dunia bermain. Anak-anak mempunyai otoritas untuk mengapresiasi kemampuannya. Ia mampu melakukan sesuatu untuk ditunjukkan kepada orang lain. Clara $\mathrm{Ng}$, pengarang sastra anak yang hebat.

Anak diajak berimajinasi mengenai 'cinta' sang ibu dengan bijaksana menerangkan dan mendekati anak dengan metafor yang ada di alam ini.

Mama mengganti kertas.

"Cinta adalah," katanya sambil mulai menggambar, "titik-titik hujan yang jatuh dari langit. Bunga bermekaran dan Kupukupu menari-nari di sekelilingnya (Clara.2017b:60).

$\mathrm{Si}$ anak tentunya belum sampai pemikirannya sehingga sang ibu terus memberikan perumpamaan mengenai cinta. Sang ibu mengajak mengambar lagi dengan objek yang lain.
"Pelangi melengkung indah dan kamu berkecipak-kecipuk di tanah basah" ((Clara.2017b:61)

Kali ini, ibu mengibaratkan cinta itu dengan pelangi dan ketika anak mainan di lumpur, ia rela diapakan saja, tetapi tidak membalas dengan kejelekan.Mama menganti kertas lagi.

"Cinta adalah," katanya, "belajar dan bermain di sekolah. Menyapa guru dan sahabat sejati(Clara.2017b:62).

"Cinta adalah," kata Lulu sambil mulai menggambar, "tidak memilih teman waktu bermain bersama. Hitam-putih, besar-putih, gemuk-kurus, tinggi-rendah. Semua teman unik dan istimewa (Clara.2017b:65).

Anak diajarkan harus menhormati kepada semua manusia. Manusia saling menerima dan memberi. Perbedaan kulit, golongan, dan jabatan sebenarnya hanya perbedaan status belaka.

"Saat aku gembira dan sedih, Mama memeluk dan menciumku. Mengatakan semuanya akan baik-baik saja. Sehingga aku dapat tidur dengan aman sampai pagi tiba" (Clara.2017b:71).

Akhirnya anak dengan cara demikian dapat mengerti bahwa ini itu adalah sikap memberi kepada orang lain. Bagaikan matahari yang menyinari alam tanpa minta balasan. Cinta kepada guru dan teman kita tegur sapa ketika berjumpa, jika mereka bersedih kita menghiburnya, dan seterusnya. Mengenai cinta seorang anak kepada ibunya didasari kebutuhan perlindungan, demikian pula cinta ibu kepada anak adanya keinginan melindungi (Minderop, 2011: 45). Esensi cinta adalah perasaan tertarik kepada pihak lain harapan sebaliknya. Cinta diikuti dengan perasaan setia, sayang, dan tidak mementingkan diri sendiri.

Di cerita ini Clara $\mathrm{Ng}$, bercerita perilaku manusia melalui perilaku binatang/ fabel. Ada kemiripan perilaku manusia dengan binatang. Pengarang 
dengan lembut ingin menanamkan moral kepada anak agar kelak dewasa menjadi insan berkepribadian yang paripurna. Kutipan di bahwa ini mengisyaratkan kepada orang tua/ pendidik bagaimana sebenarnya mengenalkan kepribadian kepada anak.

Psikososial Inisiatif versus Kesalahan Inisiatif dipakai untuk memilih dan mengejar berbagai tujuan, seperti kawin dengan ibu/ayah, atau meninggalkan rumah, juga untuk menekan atau menunda suatu tujuan. Tujuan yang harus dihambat akan menimbulkan rasa dosa. Anak sudah belajar apa yang dilarang, tetapi ambisinya tidak terbatas sehingga menjadi agresif dan manipulatif dalam mencari tujuan. Keberanian yang berlebihan dan melanggar moral, fantasi seksual, dan perasaan moral menjadi tanggung jawab moral menjadi pemicu rasa berdoasa. Konflik antara inisiatif dengan berdosa menjadi krisis psikososial yang dominan pada usia bermain (Alwisol, 2014: 95).

Usia bermain juga merupakan tahap di mana anak mulai mengembangkan konsensia dan memberi label "benar" atau "salah" terhadap tingkah lakunya. Konsensia itu akan menjadi awal perkembangan moralitas. Clara menceritakan ada seorang anak yang bernama Pipi ditinggal meninggal ibunya. Pipi bertanya kepada ayah, bagaimana keadaan bunda di alam kubur. Sang ayah menjawab seperti kutipan di bawah ini.

Malam semakin luruh, bintang-bintang semakin bersinar terang. Pipi dan Ayah duduk berdua, memandang langit sambil menyorotkan senter ke atas. Berkelipkelip. Tiga kali. Itu artinya. Pipi cinta Bunda. Pipi tersenyum ketika air mata meleleh di pipinya. Bintang, tetaplah bersinar agar Pipi tahu Bunda baik-baik saja di atas sana (Clara.2017a:74).
Ayah memberikan penjelasan kepada Pipi, jika siapa pun yang meninggal dunia akan menerima balasan amal ketika ia masih hidup. Bila mana ia berbuat baik, maka akan bercahaya atau bersinar seperti senter yang bisa bersinar, bisa menerangi kegelapan. Nah, dengan demikian sang anak akan berinisiatif bahwa orang yang baik akan mendapatkan suatu pahala kebajikan. Sebaliknya jika mereka berbuat jelek akan dibuat gelap alam kuburnya. Sehingga anak akan berbuat baik dan menjauhi perbuatan dosa.

Psikososial Integritas versus

Keputusasaan Kemampuan untuk mewujudkan semua tujuan individu sesuai dengan apa yang dikehendaki adalah integritas. Integritas dapat dicapai mana kala disusun rapi dan disiplin. Kadang apa yang sudah direncanakan begitu baik tapi keberhasilan belum maksimal, maka individu tersebut akan mengalami sikap keputusasaan. Hidup tidak bersemangat, suka mengeluh dan bersedih hati. Oleh karena itu, jika individu mengalami hal yang demikian maka harus ada motivasi dari orang tua. Nico ingin memberitahukan kepada Reza, temanya yang memandang sebelah mata terhadap anak disabel.perhatikan kutipannya di bawah ini.

Mata Nico kini berbinar. "Benar kata Ibu" seru Nico bersemangat. "Besok akan kuceritakan tentang Kak Mila kepada Reza. Biar kutunjukkan piagam penghargaan juara kelas milik Kak Mila. Aku tidak sabar melihat reaksi kagum Reza." Ibu memeluk Nico. "Anak pintar!" serunya gembira. "Ini baru Jagoaan Ibu!" (Clara.2017b:122).

Anak disabilitas, anak yang tumbuh dengan keterbatasan. Keterbatasan bukan merupakan penghalang baginya untuk berkarya seperti Mila. Mila mempunyai segudang prestasi. Mila masih diberikan kelebihan 
di bidang lain oleh Tuhan. Banyak di antara mereka yang menjadi inspirator kemajuan di berbagai bidang kehidupan. Mereka bisa berkarya untuk masyarakat dan bangsa.

Keberhasila Kapten kebakaran mendapatkan ancungan jempol dari warga kebakaran. Mereka berhasil mengalahkan si jago merah dengan cepat. Rasa puas itu disyukuri oleh semua warga, jika tidak ya kekecewaan yang ada di dapatkan. Perhatikan kutipan berikut ini.

Sirene mobil pemadam kebakaran, ambulans, dan mobil polisi berbunyi nyaring ketika semuanya bergerak meninggalkan lokasi kebakaran. Orangorang bertepuk tangan sepanjang jalan, merasa lega karena api telah padam sekaligus memberikan semangat kepada para pahlawan yang telah menjadi pelindung kota. HORE! (Clara.2017b:144).

Di sini, Anak sudah berpikir realita tentang kebakaran membutuhkan pertolongan dari pihak lain, terutama petugas pemadam kebakaran, kesehatan dan pihak keamanan (polisi). Keberhasilan bukan ditentukan oleh satu pihak, tetapi keberhasilan ditentukan oleh kekompakan berbagai elemen yang ada.

Ada putri raja Sofi menyuruh sang raja mengambil bulan, tentu cerita ini fiktif belaka. Manusia bisa naik ke bulan jika dibantu dengan alat. Cerita ini, memberikan gambaran kepada manusia, jika menginginkan sesuatu harus diraihnya dengan sungguh-sungguh dan cara yang benar. Untuk mencapai sesuatu dibutuhkan bantuan orang lain. Tidak ada orang sukses dengan kekuatannya sendiri. Ingat kita makhluk sosial. Mulai dari lahir sampai mati lagi masih membutuhkan orang lain. Demikian juga sang raja ini bisa berhasil juga bantuan dari berbagai pihak. Perhatikan kutipan berikut.
Raja tersenyum puas. Juru Masak, Kesatria, Tukang Kebun berpelukan dan meloncat-loncat kegirangan. Akhirnya, mereka semua kembali ke istana dan hidup bahagia selama-lamanya ((Clara, 2017b:192).

Keberhasilan patutlah disyukuri dan dirayakan bersama. "Bulan" oleh pengarang di sini diumpamakan dengan "suatu" kemenangan atau keberhasilan yang telah diraih dengan berbagai usaha dan metode. Dengan metode kehidupan akan menjadi mudah.

\section{SIMPULAN DAN SARAN}

Psikososial Kepercayaan versus Kecurigaan Anak percaya bahwa kehidupan bisa aman, tenang, dan nyaman bila dekat dengan orang tua. anak mendapatkan fasilitas untuk tumbuh dan berkembang. Anak bisa mengembangkan kepercayaan dasar (sintonik) sesuai dengan lingkungan kulturalnya. Sebaliknya jika tidak ia akan mengembangkan ketidak percayaan (distonik). Psikososial Kepercayaan versus Kecurigaan dapat ditemukan pada dongeng Buku Bagai Bumi Berhenti Berputar. pada judul Pohon Harapan,Seribu Sahabat Selamanya, dan judul Kerdip Bintang di Langit.

Psikososial Otonomi versus Perasaan Malu Anak belajar mengenal hak dan kewajiban serta pembatasanpembatasan tingkah laku, belajar mengontrol diri sendiri dan menerima kontrol dari orang lain. Berangsur-angsur keberhasilan mengontrol tubuh menimbulkan perasaan otonomi menimbulan rasa bangga dan kegagalan menimbulkan perasaan malu-ragu. Psikososial ini dapat dijumpai pada Buku Bagai Bumi Berhenti Berputar pada judul Seribu Sahabat Selamanya, Jangan Lupa Aku Mencintaimu, Aku Bisa Terbang, Melukis Cinta,Milo Sedang Bosan, judul Jangan Bilang Siapa-siapa. 
Psikososial Inisiatif versus Kesalahan Anak mempunyai kreativitas untuk belajar dan mengenal lingkungan. Anak belajar pasti mengalami kesalahan. Belajar dari kesalahan, mereka menjadi mandiri dan pinter. Anak sudah belajar apa yang dilarang, tetapi ambisinya tidak terbatas sehingga menjadi agresif dan manipulatif dalam mencari tujuan. Keberanian yang berlebihan dan melanggar moral, fantasi seksual, dan perasaan moral menjadi tanggung jawab moral menjadi pemicu rasa berdosa. Psikososial ini dapat ditemukan pada buku Bagai Bumi Berhenti Berputar, pada subjudul Kerlip Bintang di Langit danJangan Lupa Aku Mencintaimu.

Psikososial Intergratif versus Keputusasaan Kemampuan anak untuk mewujudkan semua tujuannya sesuai dengan apa yang dikehendaki. Untuk mencapai integritas harus direncanakan dengan matang serta disertai disiplin. Integritas yang sudah direncanakan begitu baik tapi keberhasilan belum maksimal, maka akan menimbulkan keputusasaan. Hal ini dapat ditemukan dalam dongeng Sejuta Warna Pelangi, dengan subjudul Yang Paling Istimewa, Sore Super Sibuk dan Ambilkan Bulan yah.

\section{SARAN}

Pada penelitian ini ada tiga saran yang akan disampaikan kepada:Pengarang, tokoh yang digunakan banyak menggunakan nama Asing, lebih familier menggunakan nama-nama lokal. Kalangan anak kurang akrab dengan tokoh dalam dongeng. Clara $\mathrm{Ng}$ sudah baik untuk mengemas amanat sehingga anak tertantang untuk membaca cerita berikutnya. Pembaca, untuk bisa memahami dongeng Clara $\mathrm{Ng}$, dengan benar, maka anak harus mendapatkan bimbingan dewasa (orang tua/ guru). Dan, Peneliti, dapat memperkaya khazanah sastra Indonesia dan membuat peneliti untuk mengapresiasi karya Indonesia yang dikarang oleh sastrawan perempuan muda Indonesia.

\section{DAFTAR PUSTAKA}

Alwisol. 2014. Psikologi Kepribadian. Malang: UMM Press.

Endraswara, Suwardi. 2008. Metode Penelitian Psikologi Sastra, Teori, Langkah dan Penerapannya. Yogyakarta: FBS Universitas Negeri.

Erikson, Erik H. 2010. Childhood and Sosiety. Yogyakarta: Pustaka Pelajar.

Neuman, W. Lawrence. 2013. Metode Penelitian Sosial: Pendekatan Kualitatid dan Kuantitatif. Jakarta: Indeks.

Clara. 2017a. Bagai Bumi Berhendi Berputar. Jakarta: PT Gramedia Pustaka Utama.

Clara. 2017b. Sejuta Warna Pelangi. Jakarta: PT Gramedia Pustaka Utama.

Nurgiyantoro, Burha .2005. Teori Pengkajian Fiksi. Yogyakarta: Gajah Mada University Press.

Nurgiyantoro, Burhan. 2016. Sastra Anak, Pengantar Pemahaman Dunia Anak. Yogyakarta: Gajah Mada University Press.

Sarumpaet, Riris K. Toha, 2010. Pedoman Penelitian Sastra Anak. Jakarta: Yayasan Pustaka Obor Indonesia.

Sarwono, Sarlito Wirawan. 2014. TeoriTeori Psikologi Sosial. Jakarta: PT Raja Grafido Persada. 